\title{
Attitude Towards ICT among Visually Impaired Children of Ludhiana in Relation to Gender and Locale
}

\author{
Sunil Kumar ${ }^{1}$, Dr. Kuldeep Kaur Grewal ${ }^{2}$, Dr. Mohua Khosla ${ }^{3}$ \\ ${ }^{1}$ Research Scholar, Department of Education, CT University, Ludhiana (Punjab) INDIA \\ ${ }^{2}$ Dr. Kuldeep Kaur Grewal, HOD, CT University, Ludhiana (Punjab), INDIA \\ ${ }^{3}$ Dr.Mohua Khosla, Associate Professor, Malwa College of Education for Women, Ludhiana (Punjab), INDIA
}

\begin{abstract}
Present study was undertaken to investigate the level of attitude of visually impaired children towards ICT and to check the significance of difference in attitude towards ICT on the basis og gender and locale. 100 children 50 boy ( 25 urban and 25 rural) and 50 Girl ( 25 urban and 25 rural) were randomly selected from the list of visually impaired children in the schools of Ludhiana district of Punjab. Self-developed scale of attitude towards ICT for visually impaired was used by the investigator. Result of the study revealed that most of the children have moderate attitude towards ICT. Visually impaired children do not differ significantly on the basis of their gender and locale.
\end{abstract}

Keyword: Attitude towards ICT, visually impaired children, gender, locale.

\section{INTRODUCTION}

ICTs, which include radio, television, and newer digital innovations including computers and the internet, have been hailed as potentially important enablers of educational change and reform. Different ICTs are said to help extend educational access, improve the importance of education in the increasingly digital workplace, and increase educational quality by, among other things, assisting in the transformation of teaching and learning into an engaging, active process linked to real life.

However, the experience of integrating various ICTs in classrooms and other educational settings around the world over the past several decades indicates that complete realization of ICTs' educational potential is not automatic. The successful incorporation of ICTs into the educational system is a dynamic, multifaceted process that includes not only technology (although, given enough initial resources, having the technology is the easiest part), but also curriculum and pedagogy, institutional preparation, teacher competency, and long-term financing, among other things.

\section{Definition of ICT}

Robin Mansell and Uta (1998) state, "Advanced microelectronics-based information and communication technologies (ICTs) are at the heart of recent social and economic transformations in both the industrialized and many developing nations."

\section{ICT in education}

ICT (information and communication technology) is assisting in the advancement of innovative teaching/learning approaches. There is no question that information and communication technology (ICT) will help transform teaching and learning. However, the issue that need to be looked into are those relating to what can do and cannot do in the field of education in general, the higher education in particular. Issues includes subjects like.

I. The attitude of visually imparted children towards ICT.

II. The role of the teacher in the use of ICT

III. The teacher's competencies

IV. The role of universities/school teacher in digital era, etc.

The issue boils down to the fact that the attitude of visually imparted children towards ICT and rural and urban visual imparted children will now need new knowledge, new skills and new competencies to cope with ICT environment, consistent the changes that have been brought about in teaching/learning and their attitude process due to the introduction of ICT.

\section{Rationale of the study}

The modern age is characterized by rapid technological development. Education technology can be thought of 
DOI: $10.17148 /$ IARJSET.2021.8684

as a science of strategies and methods for achieving educational goals. The aim of this study is to find out how senior secondary school teachers feel about using technology in the classroom. According to Rajput, director of the National Council of Educational Research and Training, "the growth of universalization of education is only complete with the education and fulfilment of the special needs of the less abled children" (NCERT).Recognizing the lack of infrastructure and suitable computer teaching methodologies for visually impaired students, NCERT's Department of Education for Groups with Special Needs (DEGSN), in technical cooperation with the United Nations Educational, Scientific, and Cultural Organization (UNESCO)organized a three-day training workshop on 'braille computer system technology' recently. The implementation of 'braille display terminals,' which will assist visually impaired students in learning, applying, and exploring all computer software programmes, including the internet and email, was a unique aspect of this programme. E-learning and Special Needs Technologies, programme specialist, UNESCO, T Miloudi conducted the workshop in which teachers and teacher educators from the government and non-government organizations participated. The lack of appropriate e-learning methodology has hampered the development of special children. Many of them are unable to seek higher education abroad, use the internet, or even work efficiently on a computer for their needs due to their disabilities. Miloudi says, "One of the greatest success of this programme is that it will make virtual learning easy for them as they can access the Internet and email." So this is the need of the study to know about the attitude of visually impaired children towards information technology. It is hoped that the outcomes of this study can be used in shaping innovational practices in the education of visually impaired children.

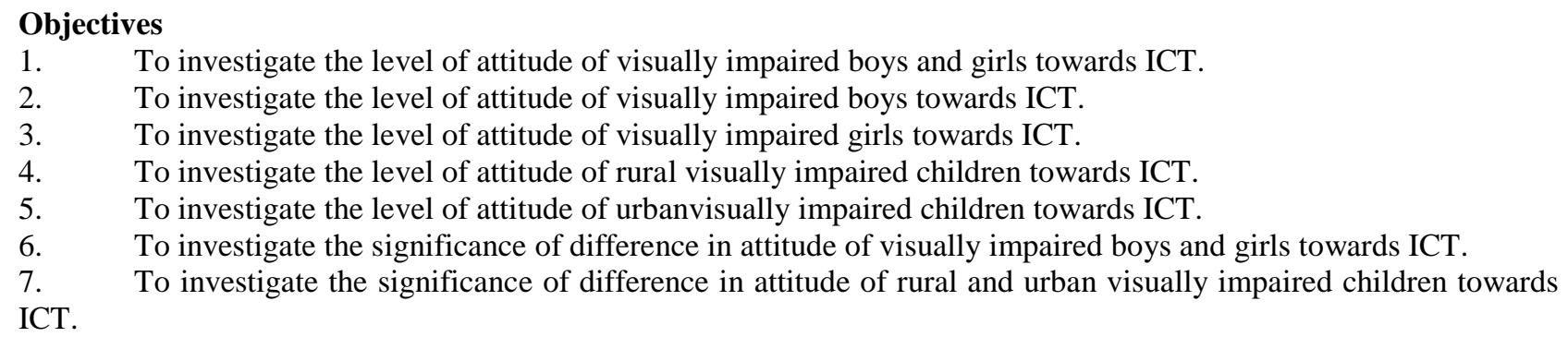

Hypotheses

1. There is no significant difference in the attitude of visually impaired boys and girls towards ICT.

2. There is no significant difference in the attitude of rural and urban visually impaired children towards ICT.

Method: Descriptive survey method was used in the study.

Sample: The list of existing visually impaired children studying in Government and Private schools of Ludhiana district was collected from the District Education Office \& Director of Public Instructions (schools). Out of these children, 100 children 50 boy $(25$ urban and 25 rural $) \quad$ and 50 Girl (25 urban and 25 rural) was randomly selected for the purpose of data collection.

\section{Delimitation}

The study was confined to visual impaired children of 10-13 years (age group)

Tool: Self-prepared Scale of Attitude towards ICT for visually impaired was used in the present study. The scale has 25 questions, each question has four options. Positive items have 3,2,1,0 marks and negative items have 0,1,2,3. In this test maximum numbers a student can obtained was 75 .

\section{Result}

On the basis of the tool it was found that $48 \%$ of visually impaired boys and girls were having moderate attitude towards the ICT.36\% of visually impaired boys and girls were having favorable attitude towards ICT. Only $16 \%$ boys and girls were found with the unfavorable attitude towards the ICT.

$44 \%$ of visually impaired boys were having moderate attitude towards the ICT.38\% of visually impaired boys were having favorable attitude towards ICT. Only $18 \%$ visually impaired boys were found with the unfavorable attitude towards the ICT.

$52 \%$ of visually impaired girls were having moderate attitude towards the ICT.34\% of visually impaired girls were having favorable attitude towards ICT. Only 14\% visually impaired girls was found with the extremely unfavorable attitude towards the ICT.

$46 \%$ of rural visually impaired children were having moderate attitude towards the ICT.36\% of rural visually impaired children were having favorable attitude towards ICT. Only 16\% rural visually impaired children was found with the 


\section{International Advanced Research Journal in Science, Engineering and Technology}

Vol. 8, Issue 6, June 2021

DOI: $10.17148 /$ IARJSET.2021.8684

unfavorable attitude towards the ICT.

$50 \%$ of urban visually impaired children were having moderate attitude towards the ICT.38\% of urban visually impaired children were having favorable attitude towards ICT. Only 16\% urban visually impaired children were found with the extremely unfavorable attitude towards the ICT.

\section{Comparison of the Attitude of visually impaired boys and girls towards ICT}

Mean, Standard deviation and t-value was calculate to compare the attitude of visually impaired boys and girls towards ICT. The results are given in Table 1 below:

Table 1: Significance of difference between mean score of Attitude of Visually impaired boys and girls towards ICT

\begin{tabular}{|l|c|c|c|c|}
\hline Group & $\mathbf{N}$ & Mean & Standard Deviation & t-value \\
\hline Boy & 50 & 43.23 & 10.85 & \multirow{2}{*}{1.50} \\
\hline Girl & 50 & 41.86 & 10.34 & \\
\hline
\end{tabular}

From the Table 1, it is evident that the mean values of attitude towards ICT for boys and girls are 43.23 and 41.86 respectively. The t-value is 1.50 , which is not significant ( $p>0.05)$. It indicates that the mean scores of the attitude of visually impaired boys and girls towards ICT do not differ significantly. Null hypothesis, "There is no significant difference between boy and girl visually impaired children towards ICT", thusstands accepted. It may, therefore, be said that visually impaired boys and girls do not differ significantly in their attitude towards ICT .

\section{Comparison of the Attitude of visually impaired rural and urban towards ICT}

Mean, Standard deviation and t-value was calculate to compare the attitude of visually impaired rural and urban towards ICT. The results are given in Table 2 below:

Table 2: Significance of difference between mean score of Attitude of rural and urban Visually impaired children towards ICT

\begin{tabular}{|l|c|c|c|c|}
\hline Group & $\mathrm{N}$ & Mean & Standard Deviation & t-value \\
\hline Rural & 50 & 41.12 & 9.38 & \multirow{2}{*}{1.62} \\
\hline Urban & 50 & 43.56 & 10.11 & \\
\hline
\end{tabular}

From the Table 2, it is evident that the mean values of attitude towards ICT for rural and urban are 41.12 and 43.56 respectively. The $t$-value is 1.62 , which is not significant $(p>0.05)$.It indicates that the mean scores of the attitude of rural and urban visually impaired children towards ICT do not differ significantly. In the light of this the null hypothesis, namely, "There is no significant difference between rural and urban visually impaired children towards ICT", is stand accepted. It may, therefore, be said that rural and urban visually impaired children do not differ significantly in their attitude towards ICT.

\section{Implications}

Result of the study shows that most of the visually impaired children have moderate attitude towards ICT. They do not differ in their attitude towards ICT on the basis of gender and locale. It is thus suggested to teachers and parents to expose these children to ICT irrespective of gender and locale.. Equipment of ICT adapted according to the needs of visually impaired need to be provided in the school. Encouragement and conducive environment will be helpful in developing proper attitude towards ICT.

\section{REFERENCES}

[1]. Alam, M. (2006). Kumar's Super Guide UGC, Vee Kumar, Publication Pvt. Ltd., New Delhi.

[2]. Anderson, P. (2006). The Future of Human-Computer Interaction" in Emerging Technologies for Learning, BECTA, accessed February 2010 http://becta.org.uk/corporate/publications/documents/Emerging_Technologies.pdf

[3]. Anohina, A. (2005). Analysis of the terminology used in the field of virtual learning Educational Technology \& Society, 8(3), 91-102.

[4]. Berman, Sally D. (2008). ICT Based Distance Education in South Asia. International Review of Research in Open and Distance Learning. http://eric.ed.gov/

[5]. Burzagli, L., Emiliani, P.L., \&Graziani, P., (2004). Accessibility in the Field of Education. Lecture Notes in Computer Science, Germany: Springer-Verlag, ISSU 3196, 235-241.

[6]. Choudhary, K. (2012). Psychological Perspectives on Physically Disabled Children.International Journal of Basic and Advanced Research, 1(3), 2278-7143. Available at www.ijbar.impactfactor.org

[7]. Dini, S., Ferlino, L., Gettani, A., Martinoli, C., \&Ott, M. (2006). Educational software and low vision students: evaluating accessibility factors. Universal Access in the Information Society, Springer Berlin / Heidelberg, ISSN 1615-5289 (Print) 1615-5297 (Online), 2006

[8]. Farrell, Glen, Ed. (2004), ICT and Literacy: Who Benefits? Experience from Zambia and India. Commonwealth of Learning. http://eric.ed.gov/

[9]. Good, C.V. (1959). Dictionary of Education (Second Edition), New York, McGraw Hill, 493-510.

[10]. Hawes, G.R. and Hawes, L.S. (1987). The Concise Dictionary of Education, Nostrand Company, New York. 


\section{International Advanced Research Journal in Science, Engineering and Technology}

Vol. 8, Issue 6, June 2021

\section{DOI: $10.17148 /$ IARJSET.2021.8684}

[11]. Kasomo, D. (2012). Psychological Assessment of Visual Impaired Children in Integrated and Special Schools.Education, 2(1), 35-40. Available at http://article.sapub.org/10.5923.j.edu.20120201.07.html.

[12]. Katyal, S. and Bindra (1995). Academic Achievement: Some Determine, Indian Psychological Review. 44: 25-96.

[13]. Kumar, S. and Gagan, M. (2007). True Man's Specific Series UGC, Danika Publishing Company, New Delhi.

[14]. Kumari, S. (2001). Learning Strategies, Achievement Motivation and Academic Performance of High School Students, unpublished M.Ed. Dissertation, PU, Chandigarh.

[15]. Ladson, B.G. (1999). Can anybody teach children? The premise of culturally relevant teaching. Teaching today for tomorrow. Issue 1,2 spring.

[16]. Nielsen, J., (2001), Beyond ALT Text: Making the Web Easy to Use for Users with Disabilities. NN/ gcomreports / accessibility, http://www.nngroup.com/reports/accessibility/.

[17]. Parveen, C. (2006). Tapping creativity, Collaboration and Cooperation for Quality in Teacher Education, Online Submission, Paper presented at the CTE State Convention \& Seminar on TQM. http://eric.ed.gov/

[18]. Powar, K. B., Tiwari, M.D. and Dikshit, H. P. (2002), ICT Enabled Education, Published by Associations of Indian Universities, New Delhi.

[19]. Sanchez, Jaime: Salines, Alvaro (2008). ICT \& learning in Chilean School Computers \& Education, Journal Articles; Reports- Evaluative. http://eric.ed.gov/

[20]. Stephen, J.H. (1956). The study of Educational Growth, Educational Psychology Henoay Holland Company, New York, pp. $209-210$.

[21]. Yeshi Ngima; Dorjee Tsering. "Impact of COVID-19 on Education". International Research Journal on Advanced Science Hub, 2, Special Issue ICAMET 10S, 2020, 34-39. doi: 10.47392/irjash.2020.196

[22]. Thomdike, R.L. (1926). Measurement of Intelligence, New York Bureau of Publication, Teacher College, Columbia University.

[23]. Torres, P. (1994). The use of computers assisted instruction in the teaching of handwriting skills. Dissertation abstract, pp 10-19.

[24]. Tubin, Dorit (2007). When ICT meets School: Differentiation, Complexity and Adaptability. Journal of Educational Administration, http://eric.ed.gov/

[25]. Viisola, M., (1999). Statistics on Children with Visual Impairments. ERIC Education Resource Information Center Publication ED432106. Retrieved on February 15, 2010 from http://eric.ed.gov

[26]. Wong, Emily M L., LiSandy, S. C. Choi, Tat-heung, Lee, Tsz-ngong (2008). "Insight into innovative classroom practices with ICT." Identify the impetus for change. Educational Technology and Society. Journal Articles, Report-Evaluative. http://eric.ed.gov/

[27]. World Health Organization, WHO (2004). Magnitude and causes of visual impairment. Fact Sheet $\mathrm{N}^{\circ} 282$ accessed February 2010 http://www.who.int/mediacentre/factsheets/fs282/en/print.html 